\title{
Effects of Cadmium on Carbonic Anhydrase and Activities Dependent on Electron Transport of Isolated Chloroplasts ${ }^{1}$
}

\author{
Carmen I. Asencio and Arturo Cedeño-Maldonado ${ }^{2}$ \\ ABSTRACT
}

\begin{abstract}
Low concentrations of Cadmium inhibit the electron transport and $\mathrm{CO}_{2}$ fixation reactions of isolated chloroplasts. $\mathrm{CO}_{2}$ fixation is more sensitive to $\mathrm{Cd}$ than electron transport and dark pre-incubation increases the degree of toxicity to both. Carbonic anhydrase, an enzyme associated with $\mathrm{CO}_{2}$ fixation, is very sensitive to $\mathrm{Cd}$ either when applied directly to partially purified preparations of the enzyme or when enzyme preparations are obtained from intact chloroplasts previously exposed to $\mathrm{Cd}$. Strong inhibition occurs at $\mathrm{Cd}$ concentrations lower than those required to inhibit any of the electron transport dependent reactions studied. These results are interpreted as evidence that carbonic anhydrase is one of the most sensitive sites of $\mathrm{Cd}$ action in isolated chloroplasts.
\end{abstract}

\section{INTRODUCTION}

Cadmium, a non-essential element in plant nutrition, accumulates in different tissues and impairs plant growth. Recent evidence indicates that cadmium inhibits whole plant photosynthesis (1) and the electron transport activities of isolated chloroplasts (2). The early events in the oxidizing side of photosystem II are considered to be the most sensitive site of inhibition in the electron transport chain of isolated chloroplasts. Inhibition of whole plant photosynthesis occurs at concentrations lower than those required for strong inhibition of electron transport, indicating the possibility of additional sites of action. The present work presents evidence showing that in the isolated chloroplast, the activity of carbonic anhydrase, an enzyme associated with photosynthetic $\mathrm{CO}_{2}$ fixation, is even more sensitive to $\mathrm{Cd}$ than electron transport.

\section{MATERIALS AND METHODS}

The bean plants (Phaseolus vulgaris L. cv. Jamapa) used in these experiments were grown under greenhouse conditions in 6-in diameter plastic pots containing sterilized soil. Chloroplasts were extracted from fully expanded trifoliolate leaves, when the plants were approximately 2 weeks old.

' Manuscript submitted to Editorial Board March 31, 1978.

${ }^{2}$ Research Associate, Center for Energy and Environment Research now instructor, Department of Biology, Catholic University of Puerto Rico, Ponce, P.R.; and Assistant Professor, Department of Horticulture, Mayagüez Campus, University of Puerto Rico, Mayagüez, P.R. 
Chloroplasts used in all the experiments were isolated by the method of Robinson and Stocking (10). Solutions A and B used contained $50 \mathrm{mM}$ sorbitol, $40 \mathrm{mM}$ isoascorbate, $40 \mathrm{mM} \mathrm{NaNO}$, $20 \mathrm{mM} \mathrm{MnCl}_{2}$, and $20 \mathrm{mM}$ $\mathrm{MgCl}_{2}$. In addition, solution A contained $20 \mathrm{mM}$ disodium ethylenediamine tetraacetate (EDTA), $50 \mathrm{mM}$ 2-(N-morpholino) ethanesulfonic acid (MES), and $20 \mathrm{mM} \mathrm{CaCl}_{2}$ with a $\mathrm{pH}$ of 6.1 , and solution $\mathrm{B}$ contained 50 $\mathrm{mM}$ N-2-hydroxyethyl-piperazine-N'-2-ethanesulfonic acid (HEPES) and $20 \mathrm{mM} \mathrm{NaCl}$ with $\mathrm{pH}$ adjusted to 6.7 .

Chlorophyll content was measured by the method of Arnon (1). The degree of inhibition of electron transport associated with PS II activity was determined by measuring changes in oxygen concentration polarographically as described by Cedeño-Maldonado et al. (2). The assay solution contained $100 \mathrm{ug}$ chlorophyll, $50 \mathrm{mM}$ HEPES, 1. mM KCN, and

TABLE 1.-Effect of different concentrations of Cd on PS II activity of isolated chloroplasts

\begin{tabular}{ccc}
\hline$\mu \mathrm{M} \mathrm{CdCl}_{2}$ & Oxygen evolution & \% Inhibition \\
\hline 0 & 50 & 0 \\
100 & 50 & 0 \\
200 & 43 & 13 \\
250 & 35 & 30 \\
350 & 30 & 39 \\
500 & 24 & 52 \\
650 & 21 & 58
\end{tabular}

'Assay medium contained: $50 \mathrm{mM} \mathrm{HEPES}, 0.4 \mathrm{mM} \mathrm{K} \mathrm{Fe}_{3}(\mathrm{CN})_{6}, 10 \mathrm{mM} \mathrm{KCN}$, and chloroplasts at a chlorophyll concentration of $100 \mu \mathrm{g} / 1.75 \mathrm{ml}$. Oxygen evolution is given in umoles $0_{2} / \mathrm{mg}$ chlorophyll/hr.

$0.4 \mathrm{mM} \mathrm{K}_{3} \mathrm{Fe}(\mathrm{CN})_{6}$. The preparations were uncoupled by adding $100 \mathrm{uM}$ $\left(\mathrm{NH}_{4}\right)_{2} \mathrm{SO}_{4}$. The effect of Cadmium on PS II and in all the experiments discussed in this work were determined by adding different concentrations of $\mathrm{CdCl}_{2}$ to the reaction mixtures.

To explore the possible participation of $\mathrm{Cd}$ in inhibition of $\mathrm{CO}_{2}$ fixation, $\mathrm{O}_{2}$ evolution was determined with preparations of intact chloroplasts. These chloroplasts were obtained from leaves which had been exposed to 24 hours of darkness before extraction. The reaction media in these experiments contained $100 \mu \mathrm{g}$ chlorophyll, $100 \mathrm{mM} \mathrm{K} \mathrm{HPO}_{4}, 5 \mathrm{mM}$ $\mathrm{MgCl}_{2}, 10 \mathrm{mM} \mathrm{KCN}$, and $50 \mathrm{mM}$ HEPES. The mixture was saturated with gaseous $\mathrm{CO}_{2}$ before oxygen evolution was measured.

For assaying carbonic anhydrase activity, chloroplast preparations suspended in solution B were centrifuged and re-suspended in $20 \mathrm{mM}$ sodium diethyl barbiturate, $\mathrm{pH} 8.0$, to break the chloroplasts and liberate the enzyme. The lysed chloroplasts were then centrifuged for $15 \mathrm{~min}$ at 4,000 g. The supernatant (enzyme extract) was used to obtain a partially 
purified enzyme preparation by the method described by Everson (4). Carbonic anhydrase activity was measured by the method described by Chang (3).

Since carbonic anhydrase is associated with the stroma, intact chloroplasts had to be employed to determine whether $\mathrm{Cd}$ was reaching the enzyme by penetration through the chloroplast membranes. Chloroplasts at a chlorophyll concentration of $100 \mathrm{mg}$ were suspended in test tubes containing solution $\mathrm{B}$ and $50 \mathrm{mM} \mathrm{CdCl}$. The tubes were kept in darkness from 0 to $30 \mathrm{~min}$., and then centrifuged for $2 \mathrm{~min}$. at 2,000 g. The resultant pellet was washed with cadmium-free medium and centrifuged again. The remaining pellet was then resuspended for $15 \mathrm{~min}$. in $5 \mathrm{ml}$ veronal buffer to rupture the chloroplasts and release the enzyme, and then centrifuged for $15 \mathrm{~min}$ at $4,000 \mathrm{~g}$. The supernatant (enzyme extract) was used for assaying carbonic anhydrase activity.

TABLE 2.-Effect of dark incubation on inhibition by Cd of PS II activity in isolated chloroplasts ${ }^{1}$

\begin{tabular}{cccccc}
\hline \multirow{2}{*}{$\mu \mathrm{M} \mathrm{CdCl}_{2}$} & \multicolumn{2}{c}{$0_{2}$ Evolved } & & \multicolumn{2}{c}{ \% Inhibition } \\
\cline { 2 - 3 } \cline { 5 - 6 } & $0 \mathrm{~min}$ & $10 \mathrm{~min}$ & & $0 \mathrm{~min}$ & $10 \mathrm{~min}$ \\
\hline 0 & 37.5 & 34.3 & & 0 & 0 \\
100 & 37.5 & 37.5 & & 0 & 0 \\
250 & 27.0 & 17.9 & & 28.1 & 47.8 \\
350 & 20.9 & 15.8 & & 44.3 & 54.0 \\
500 & 21.7 & 11.9 & & 42.0 & 65.2 \\
\hline
\end{tabular}

'Assay medium contained: $50 \mathrm{mM} \mathrm{HEPES}, 0.4 \mathrm{mM} \mathrm{K}{ }_{3} \mathrm{Fe}(\mathrm{CN})_{6}, 10 \mathrm{mM} \mathrm{KCN}$, and chloroplasts at a chlorophyll concentration of $100 \mu \mathrm{g} / 1.75 \mathrm{ml}$. Oxygen evolution is given in umoles $\mathrm{O}_{2} / \mathrm{mg}$ / chlorophyll hr.

\section{RESULTS AND DISCUSSION}

The effect of cadmium on oxygen evolution associated with PS II activity was determined by the use of $\mathrm{K}_{3} \mathrm{Fe}(\mathrm{CN})_{6}$ as electron acceptor. Results shown in table 1 demonstrate the degree of inhibition produced in this photosystem. Inhibition was observed at $\mathrm{CdCl}_{2}$ concentrations exceeding $200 \mu \mathrm{M}$, and concentrations exceeding $500 \mu \mathrm{M}$ were required to obtain over $50 \%$ inhibition of PS II electron flow activity. Willing (12) reported 35\% inhibition with $300 \mu \mathrm{M}$ Cd; and Li and Miles (9) found $20 \%$ inhibition with concentrations between 100 and $300 \mu \mathrm{M} \mathrm{Cd}$, which are comparable to the results presented in table 1.

Since previous studies with heavy metals (2) have shown that exposure of preparations to periods of dark pre-incubations could change the pattern of toxicity, an experiment was performed to reveal the behavior of $\mathrm{Cd}$ in this respect. In darkness the chloroplast samples were preincubated for $10 \mathrm{~min}$ at $25 \mathrm{C}$ with preparations containing $\mathrm{Cd}$ before 
being assayed. The effect of dark pre-incubation on PS II activity is shown in table 2. Dark incubation had considerable effect on the degree of inhibition in this assay system, especially at high $\mathrm{Cd}$ concentrations. Apparently, some time is required for $\mathrm{Cd}$ to reach the sensitive sites of PS II and to exert its inhibitory action. In this respect the action of $\mathrm{Cd}$ is different from that of $\mathrm{Cu}$, which exerts a maximum inhibitory action immediately after its addition to chloroplast preparations (2).

A procedure for the determination of $\mathrm{CO}_{2}$-supported $\mathrm{O}_{2}$ evolution by intact chloroplasts has been recently described (5). With this procedure, experiments were performed to explore the effects of cadmium on $\mathrm{CO}_{2}$ fixation. The results shown in table 3 indicate that $\mathrm{CO}_{2}$ fixation by intact chloroplasts is inhibited by $\mathrm{Cd}$ even to a greater degree than electron transport, a fact that points to the reactions involved in $\mathrm{CO}_{2}$ fixation as sensitive sites to the action of $\mathrm{Cd}$.

TABLE 3.-Effect of different concentrations of $\mathrm{Cd}$ on $\mathrm{CO}_{2}$ supported oxygen evolution by intact chloroplasts'

\begin{tabular}{ccc}
\hline$\mu \mathrm{M} \mathrm{CdCl}_{2}$ & Oxygen evolution & \% Inhibition \\
\hline 0 & 7.7 & 0 \\
25 & 5.1 & 33 \\
50 & 4.6 & 38 \\
100 & 4.2 & 44 \\
200 & 4.2 & 44 \\
350 & 3.9 & 52 \\
450 & 1.7 & 77
\end{tabular}

' Assay mixture contained: $100 \mathrm{mM} \mathrm{K}_{2} \mathrm{HPO}_{4}, 5 \mathrm{mM} \mathrm{MgCl}_{2}, 10 \mathrm{mM} \mathrm{KCN}, 50 \mathrm{mM}$ HEPES and chloroplasts ( $100 \mu \mathrm{g}$ chlorophyll $/ 1.75 \mathrm{ml}$ ). $\mathrm{CO}_{2}$ gas was bubbled to saturate the medium. Oxygen evolution is given in umoles $0.2 / \mathrm{mg}$ chlorophyll/hr. Assay mixture was incubated in darkness for $10 \mathrm{~min}$ before the assay.

To obtain additional illustrative information on the possible mechanism of inhibition of $\mathrm{CO}_{2}$ fixation, pre-incubation experiments similar to these previously described were performed. Results are illustrated in figure 1 . A concentration of $350 \mu \mathrm{M} \mathrm{CdCl}_{2}$ was employed since it conveniently produced about $50 \%$ inhibition after $10 \mathrm{~min}$ of incubation. The degree of inhibition obtained was time dependent, increasing with incubation time. This is an indication that the sensitive sites are located inside the chloroplasts. Since all these experiments were conducted with intact chloroplasts in which $\mathrm{CO}_{2}$ is the electron acceptor, the results are indicative of the dark reactions of photosynthesis as being very sensitive to $\mathrm{Cd}$.

According to Li and Miles (9), the ultimate site of cadmium inhibition rests directly on PS II photoreaction, but Willing (12) mentioned the possibility that the primary inhibitory effects of Cd may not be due to 
effects on the electron transport system but rather to inhibition of some of the reductase enzymes involved in $\mathrm{CO}_{2}$ fixation. In whole plants $\mathrm{Cd}$ inhibits growth and photosynthesis at very low concentrations, an indication that inhibition of other photosynthetic reactions could be more sensitive to $\mathrm{Cd}$ than electron transport. Our preliminary examination of some of the enzymes involved in $\mathrm{CO}_{2}$ fixation showed that carbonic anhydrase was the most sensitive. Therefore, the effects of $\mathrm{Cd}$ on this enzyme were examined in more detail.

The effects of $\mathrm{Cd}$ on carbonic anhydrase activity were determined with enzyme preparations obtained as previously described by the electrometric method as described by Chang (3). Results are presented in table 4.

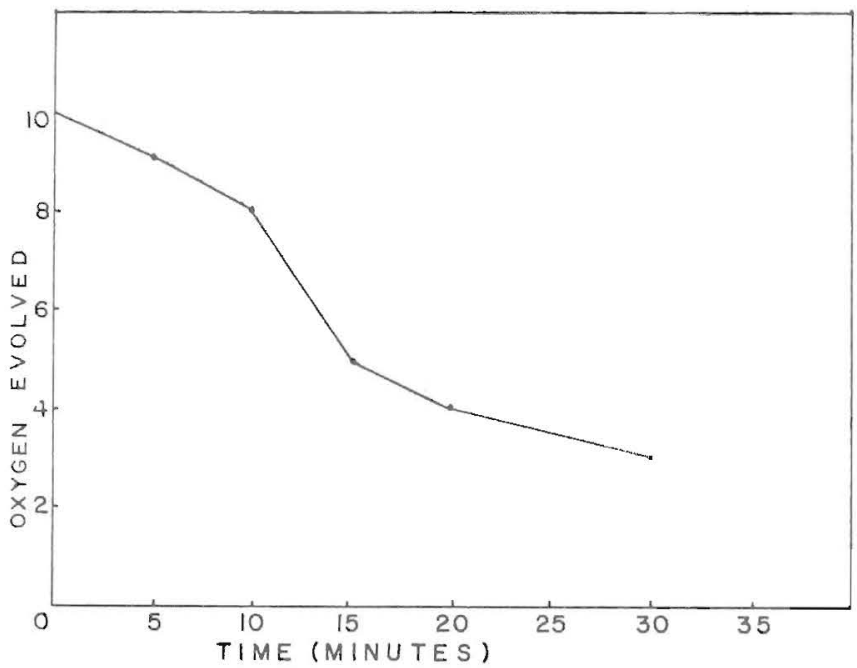

FIG. 1.-Relationship between dark pre-incubation and cadmium inhibition of $\mathrm{CO}_{2}$ supported oxygen evolution.

Carbonic anhydrase activity was strongly inhibited by Cd. Concentrations of $30 \mu \mathrm{M} \mathrm{CdCl}_{2}$ produced over $50 \%$ inhibition, and complete inhibition of enzyme activity was obtained at approximately $100 \mu \mathrm{M} \mathrm{CdCl}_{2}$. Lee et al. (8) also found that carbonic anhydrase in soybean seedlings was drastically affected with low concentrations of $\mathrm{CdSO}_{4}$.

To determine whether carbonic anhydrase activity was inhibited with Cd applied to intact chloroplasts, as was the case of inhibition of electron transport, we performed experiments in which the intact chloroplasts were incubated in $50 \mu \mathrm{M} \mathrm{CdCl}_{2}$ (which in preliminary experiments produced approximately $50 \%$ inhibition) prior to the assay. The chloroplasts were removed from the cadmium-containing solution and washed in 
cadmium-free assay medium prior to enzyme extraction. Figure 2 shows that $\mathrm{Cd}$ could readily penetrate the chloroplast membranes and inhibit carbonic anhydrase, a stromal enzyme. As in the case of electron transport, inhibition of carbonic anhydrase was time dependent, with approximately $10 \mathrm{~min}$ required for $50 \%$ inhibition. In contrast to electron transport, inhibition of this enzyme was observed at very low $\mathrm{CdCl}_{2}$ concentrations. These results point to the fact that carbonic anhydrase is one of the most important sites of action of $\mathrm{Cd}$.

Tobin (11) reported 50\% inhibition of carbonic anhydrase with $50 \mu \mathrm{M}$ sodium azide; Chang (3) reported complete inhibition with $200 \mu \mathrm{M}$ iodine; and Kisiel and Graf (7) obtained complete inhibition of this enzyme with

TABLE 4.-Effect of different concentrations of Cd on carbonic anhydrase activity of isolated chloroplasts ${ }^{1}$

\begin{tabular}{ccc}
\hline$\mu \mathrm{M} \mathrm{CdCl}_{2}$ & Units of activity & \% Inhibition \\
\hline 0 & 136 & 0 \\
8 & 112 & 18 \\
15 & 77 & 43 \\
29 & 62 & 54 \\
57 & 29 & 79 \\
83 & 19 & 86 \\
108 & 2 & 99 \\
\hline
\end{tabular}

'Reaction mixture contained: $3 \mathrm{ml} 20 \mathrm{mM}$ veronal buffer, $0.1 \mathrm{ml}$ partially purified enzyme extract, and $3.5 \mathrm{ml} \mathrm{CO} z^{-}$saturated water in a total volume of $6.6 \mathrm{ml}$. Enzyme activity is given in units of activity/mg chlorophyll.

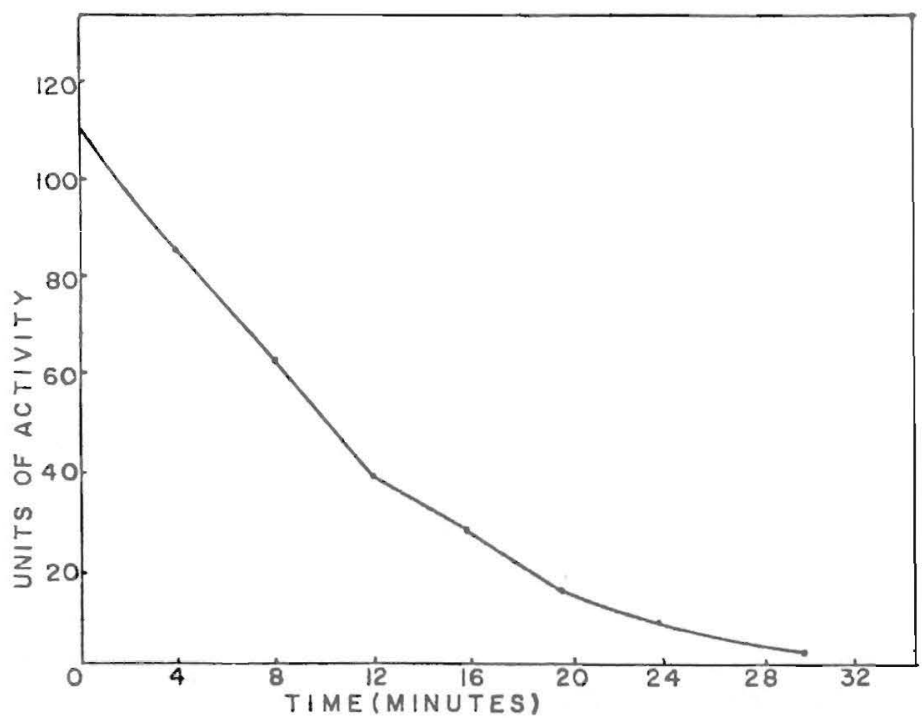

FIG. 2.-Effect of cadmium on carbonic anhydrase activity of intact chloroplasts. 
$500 \mu \mathrm{M}$ mercury after $10 \mathrm{~min}$ of incubation. The experiments of the present study, in which $50 \%$ inhibition was obtained with $50 \mu \mathrm{M} \mathrm{CdCl}_{2}$ and complete inhibition was obtained with $100 \mu \mathrm{M} \mathrm{CdCl}_{2}$, indicate that $\mathrm{Cd}$ is one of the most potent inhibitors of plant carbonic anhydrase. Since this enzyme is probably one of the key enzymes involved in regulating the levels of $\mathrm{CO}_{2}$ inside the chloroplast, its inhibition would create a disturbance of the normal metabolism of $\mathrm{CO}_{2}$. At the whole plant level this would result in an inhibition of photosynthesis which in turn could contribute to the drastic reduction in plant growth and productivity obtained when plants are exposed to low concentrations of $\mathrm{Cd}$.

\section{RESUMEN}

Concentraciones bajas de cadmio inhiben las reacciones envueltas en el transporte de electrones y la fijación de $\mathrm{CO}_{2}$ por cloroplastos aislados. La fijación de $\mathrm{CO}_{2}$ es más sensitiva al Cd que el transporte de electrones. La incubación previa en oscuridad aumenta el grado de toxicidad del Cd a ambas reacciones. La anhidrasa carbónica, enzima asociada con la fijación de $\mathrm{CO}_{2}$ es muy sensitiva al Cd cuando éste se aplica directamente a preparaciones parcialmente purificadas de la enzima o cuando se obtienen preparaciones de la enzima de cloroplastos intactos previamente expuestos a $\mathrm{Cd}$. A concentraciones bajas de $\mathrm{Cd}$ el grado de inhibición es mucho mayor que el observado en las otras reacciones estudiadas, dependientes del transporte de electrones. Se interpretan estos resultados como evidencia de que la anhidrasa carbónica es uno de los sitios más sensitivos a la acción del Cd en cloroplastos aislados.

\section{LITERATURE CITED}

1. Arnon, D. I., 1949. Copper enzymes in isolated chloroplasts. Polyphenol oxidase in Beta vulgaris, Plant Physiol. 24: 1-15.

2. Cedeño-Maldonado, A., Swader, J. A., and Heath, R. L., 1972. The cupric ion as an inhibitor of photosynthetic electron transport in isolated chloroplasts, Plant Physiol. 50: 698-701.

3. Chang, C. W., 1975. Carbon dioxide and senescence in cotton plants, Plant Physiol. 55: $515-9$.

4. Everson, R. G., 1970. Carbonic anhydrase and $\mathrm{CO}_{2}$ fixation in isolated chloroplasts, Phytochemistry 9: 25-32.

5. Heber, U., Andrews, T. J., and Boardman, N. K., 1976. Effects of $\mathrm{pH}$ and oxygen on photosynthetic reactions of intact chloroplasts, Plant Physiol. 57: 277-83.

6. Huang, C. Y., Bazzaz, F. A., and Vanderhoef, L. N., 1974. The inhibition of soybean metabolism by cadmium and lead, Plant Physiol. 54:122-4.

7. Kisiel, W. and Graf, G., 1972. Purification and characterization of carbonic anhydrase from Pisum sativum, Phytochemistry 11: 113-17.

8. Lee, K. C., Cunningham, B. A., Paulsen, G. M., Loang, G. H., and Moore, R. B., 1976. Effects of cadmium on respiration rate and activities of several enzymes in soybean seedling, Physiol. Plant 36: 4-6.

9. Li, E. H. and Miles, C. D., 1975. Effects of cadmium on photoreaction II of chloroplasts, Plant Sci. Letters 5: 33-40.

10. Robinson, J. M. and Stocking, C. R., 1968. Oxygen evolution and the permeability of the outer envelope of isolated whole chloroplasts, Plant Physiol. 43: 1597-1601.

11. Tobin, A. J., 1970. Carbonic anhydrase from parsley leaves, J. Biol. Chem. 245 (10): 2656-66.

12. Willing, R. P., 1974. Cadmium and zinc in Chlorella pyrencidosa and their effect on photosynthesis and respiration. Thesis for Master of Science. Univ. of California, Riverside. 